\title{
Is the Scottish population living dangerously? Prevalence of multiple risk factors: the Scottish Health Survey 2003
}

\author{
Richard Lawder1, Oliver Harding2, Diane Stockton'1, Colin Fischbacher1,3, David H Brewster1,3, Jim Chalmers 1,3, \\ Alan Finlayson ${ }^{1}$ and David I Conway*1,4
}

\begin{abstract}
Background: Risk factors are often considered individually, we aimed to investigate the prevalence of combinations of multiple behavioural risk factors and their association with socioeconomic determinants.

Methods: Multinomial logistic regression was used to model the associations between socioeconomic factors and multiple risk factors from data in the Scottish Health Survey 2003. Prevalence of five key risk - smoking, alcohol, diet, overweight/obesity, and physical inactivity, and their risk in relation to demographic, individual and area socioeconomic factors were assessed.
\end{abstract}

Results: Full data were available on 6,574 subjects ( $80.7 \%$ of the survey sample). Nearly the whole adult population (97.5\%) reported to have at least one behavioural risk factor; while 55\% have three or more risk factors; and nearly 20\% have four or all five risk factors. The most important determinants for having four or five multiple risk factors were low educational attainment which conferred over a 3-fold increased risk compared to high education; and residence in the most deprived communities (relative to least deprived) which had greater than 3-fold increased risk.

Conclusions: The prevalence of multiple behavioural risk factors was high and the prevalence of absence of all risk factors very low. These behavioural patterns were strongly associated with poorer socioeconomic circumstances. Policy to address factors needs to be joined up and better consider underlying socioeconomic circumstances.

\section{Background}

The World Health Organisation's Global Burden of Diseases Project identified five risk factors which contribute around $90 \%$ of the total burden of disease in high income country populations: tobacco use, alcohol consumption, poor diet, physical inactivity, overweight and obesity [1]. While epidemiological evidence is usually gathered on a single-risk factor basis [2,3], risk factors occur in individuals and populations in different combinations, and may show additive or multiplicative interactions $[4,5]$. This has implications for interventions - is it better to focus on one risk factor at a time, or to encourage motivated individuals to make more wholesale changes in their lifestyle to address more than one risk factor at a time?

* Correspondence: d.conway@dental.gla.ac.uk

${ }^{1}$ Information Services Division, NHS National Services Scotland, Gyle Square, Edinburgh, UK

Full list of author information is available at the end of the article
There are few population-based studies investigating the prevalence of combinations of risk factors [5-9]. Most studies focus on smoking; and while there is abundant evidence of the association with lifestyle and socioeconomic status, there is limited consideration of the relationship between combinations of multiple behaviours and socioeconomic factors.

Thus far analysis of risk factors in Scotland has been limited to individual risk factors such as smoking [2], alcohol [10] or diet [11]. Here we aim to use population data from the Scottish Health Survey to assess the prevalence of different combinations of multiple behavioural risk factors and to examine how these combined behaviours relate to area-based and individual socioeconomic factors.

\section{Methods}

The 2003 Scottish Health Survey is a cross-sectional national population-based survey and is the third of a 
series of surveys, the first two of which took place in 1995 and 1998. Their aim is to monitor health status and health-related lifestyles in the Scottish population. Sampling was via a multi-stage stratified probability sampling design using postcode sectors selected at the first stage and household addresses at the second stage. The survey used weights to correct for survey design (large households were underrepresented) and non-response biases. The survey methodology is described in detail elsewhere [12] and will only briefly be described here. Face-to-face interviews took place in the subject's home using Computer Assisted Personal Interviewing (CAPI), and permission was sought for a follow-up visit from a specially trained nurse. The interview covered a range of items including: self assessed health and disability, health service use, cardiovascular and respiratory disease, smoking, drinking, common mental health problems, eating patterns and physical activity and information on a range of indicators of socioeconomic position. The nurse asked further questions, for example on use of prescribed medicines, made anthropometric and biomedical measurements, including blood pressure, waist and hip circumference and lung function and collected blood and saliva samples. Saliva samples were analysed for cotinine to validate self-reported smoking [12]. Original ethical approval for the Scottish Health Survery 2003 was granted by Multicentre Research Ethics Committees. Anonymised data are accessible via the UK Data Archive for which no additional ethical approval was required.

\section{Risk factor variables}

Our analysis considered four lifestyle risk factors and obesity. Each factor was categorised in binary form respondents either having or not having the risk factor. Smoking (including cigarettes, cigars, or pipe) was defined into two categories as: current smokers versus, collectively, those who never smoked regularly, never smoked at all (with "regularly" defined as once per day for a month), or ex-smokers. Data were validated by salivary cotinine analysis. Heavy alcohol consumption was defined as exceeding the UK Royal College of Physicians definition of sensible drinking (21 units/week for men and 14 units/week for women; 1 unit of alcohol is defined as $10 \mathrm{ml}$ (8 grams) of ethanol) [13]. The dietary variable was defined by the $\mathrm{WHO}$ and national recommendation to consume five portions or more of fruit and vegetables daily $[14,15]$. Respondents were classified either as "not reaching the recommended daily intake", or "reaching the recommended daily intake". Overweight and obesity were classified following the 1999 definition of the International Obesity Task Force [16]. Thus, respondents having a BMI $\geq 25 \mathrm{~kg} / \mathrm{m}^{2}$ were classified as "overweight/obese" and those $<25$ defined as "underweight/desirable". Questions on physical activity included number of days and minutes per day of participation in: heavy housework, heavy "Do-It-Yourself" (DIY)/gardening/home maintenance, walking for any purpose, and recreational sports and exercises. Being physically active was defined by participation in at least 30 minutes of moderate exercise on five or more days of the week - based on the Allied Dunbar National Fitness Survey criteria [17]. Respondents were classified as "Meeting the recommended level of physical activity - Physically Active"; otherwise they were classified as "Physically Inactive".

The following demographic and socioeconomic variables were also included in the analysis: sex (male, female); age (grouped in the following categories: 16-39, $40-64,65+$ years); highest educational qualification (degree level or above, below degree level, no qualifications); ethnicity (white versus black and minority ethnic (BME) groups); marital status (never married, currently married, divorced/separated/widowed); economic activity status (employed, unemployed, retired, economically inactive) and the Registrar General's Occupational Social Class (I, II, III VI, V, other) for the household chief income earner. The Scottish Index of Multiple Deprivation (SIMD 2006), an area-based level of deprivation, was derived from the residential postcode of the respondents and categorised into quintiles - 1 (least deprived) to 5 (most deprived) [18]. The SIMD score is calculated at the level of "data zones" using 37 indicators from a range of administrative data sources grouped into seven domains: income, employment, housing, health, education, geographical access to services/telecommunications and crime. Data zones are stable and consistent small geographical areas in Scotland, grouped from 2001 Census Output Areas, and have populations of between 500 and 1,000 residents nested within Local Authority boundaries. They are intended to be effective at identifying small areas with similar social and economic characteristics [18].

\section{Statistical analysis}

Risk factor prevalence and 95\% confidence intervals (CI) were calculated. To ensure accurately computed estimates of the population statistics and their standard errors, sample design characteristics including stratification, multi-stage cluster sampling and probability sampling weights were taken into account. Cross-tabulations were performed to show all possible clustering patterns of the five risk factors presented.

Relative Risk Ratios (RRR) and 95\% confidence intervals were computed using multinomial logistic regression modelling to examine the independent association between each covariate and the dependent ordinal risk factor variable taking on the following four levels (zero or one risk factor, two risk factors, three risk factors, and four or five risk factors), comparing to the reference 
group of zero or one risk factor. The model included age, sex, ethnicity, education, marital status, economic activity status, occupational social class, and area-based socioeconomic circumstance (SIMD 2006). All statistical analyses were performed using Stata version 8.0 (Stata Corporation, College Station, TX, USA).

\section{Results}

The 2003 Scottish Health Survey included 8,148 adult respondents - 4,538 females and 3,610 males - representing a $67 \%$ response rate for eligible households. Full data on all five risk factors were available for $80.7 \%(n=6,574)$ of the sample, representing $54 \%$ overall response rate. Tablez 1 presents the demographic and socioeconomic profile and the prevalence of risk factors. There were more women than men in the sample, women were slightly older than men, and there were some marked differences between SIMD quintiles - particularly a lower response in those from relatively more deprived areas. Only around $2 \%$ of the sample were from BME groups and a half of men and women were currently married. Just over $20 \%$ of men and women were educated to the highest level but more women had no qualifications. There were substantially more men than women currently employed - although for those in employment the occupational social class distribution was similar. Fruit and vegetable consumption was similar in both sexes, while smoking, excessive alcohol consumption and overweight/obesity were more common and physical inactivity less common amongst men (Table 1).

\section{Multiple risk factors}

Figure 1 presents the prevalence of the combined multiple risk factors. The following summarises different combinations of risk factors:

-Number of risk factors - Only $2.5 \%$ of the sample had no risk factors. $88.2 \%$ had more than one risk factor. -Risk factors in non-smokers drinking alcohol within recommended limits - Nearly $20 \%$ of the population surveyed were overweight/obese, physically inactive and had a poor diet without other risk factors (Table 2); $10 \%$ were physically inactive and had a poor diet; $8 \%$ were physically active but had a poor diet and were overweight/obese.

-Risk factors in smokers and risk alcohol drinkers -The combination of excessive alcohol consumption and smoking was found in $9 \%$ of respondents. This group tended to have more additional risk factors - nearly three quarters had a total of 4 or 5 risk factors present, the majority being overweight or obese. Of those who drank to excess but did not smoke (12\%), 70\% were overweight or obese, usually in combination with poor diet, physical inactivity or both. Of those who smoked but did not drink to excess (23\%) more than half were overweight or obese (97\% of overweight/obese smokers having poor diet, taking insufficient physical activity or both).

Relative to zero or one risk factor, combinations of two or three multiple risk factors were significantly more common among men than women, and among those living in the most deprived communities relative to least deprived communities (Table 3). This association was also observed for those with relatively low educational attainment or lower occupational social class. Retired groups had significantly greater probability of multiple risk factors than other levels of economic activity. BME groups had lower probability of combinations of two or three risk factors compared to white counterparts. Similar but generally much stronger results were observed for combinations of four or five multiple risk factors but increased probabilities were also associated with those in economically inactive groups and in those with divorced, separated or widowed marital status.

Of all factors assessed those living in the most deprived areas and those with no educational qualifications had the greatest probability of accumulating multiple behavioural risk factors, with over a 3 fold increase associated with combinations of four or five risk factors. The SIMD profile of those included with all five variables $(80 \%)$ and those excluded in the analysis $(20 \%)$ were significantly correlated, $\mathrm{p}=0.02$ (data not shown).

\section{Discussion}

The Scottish population seems to be living dangerously. Considering five major risk factors to health - cigarette smoking, heavy alcohol consumption, poor diet, physical inactivity, and overweight - nearly the whole adult population $(97.5 \%)$ have at least one behavioural risk factor; $86 \%$ have at least two risk factors; $55 \%$ have three or more risk factors; and nearly $20 \%$ have four or all five risk factors. This study also shows that when considering single behavioural risk factors in isolation, one would reasonably expect that a substantial proportion of the population will not have the risk factor in question. However, even the most prevalent risk factor - poor diet - is present in $80 \%$ of the population. But only $2.5 \%$ of the population was without any of the five behavioural risk factors. Is this surprising? Our analysis shows that around two-thirds of the Scottish population is overweight or obese, a similar proportion are not sufficiently physically active, and most people have a poor diet - it is just that it is not the same majority for each factor. The most important determinants of multiple risk factors were low educational attainment and residence in the most deprived communities.

The main limitation of our study is common to most studies investigating prevalence of risk factors in a population - that is, it is a cross-sectional survey and therefore cannot be used to determine causal associations. Further- 
Table 1: Demographic, socioeconomic and behavioural risk factor profile of study sample by sex

\begin{tabular}{|c|c|c|c|}
\hline & Men $(n=2,941) \%(95 \% C l)$ & Women $(n=3,633) \%(95 \% \mathrm{Cl})$ & Total $(n=6,574) \%(95 \% \mathrm{Cl})$ \\
\hline \multicolumn{4}{|l|}{ Age (years) } \\
\hline $16-24$ & $14.7(12.6,17.0)$ & $12.4(10.9,14.1)$ & $13.5(12.1,15.0)$ \\
\hline $25-34$ & $16.0(14.3,17.7)$ & $15.7(14.4,17.1)$ & $15.8(14.6,17.1)$ \\
\hline $35-44$ & $19.9(18.4,21.6)$ & $20.1(18.7,21.7)$ & $20.0(18.8,21.4)$ \\
\hline $45-54$ & $17.7(16.2,19.4)$ & $16.9(15.7,18.1)$ & $17.3(16.2,18.4)$ \\
\hline $55-64$ & $15.3(13.9,16.9)$ & $15.0(13.8,16.1)$ & $15.1(14.1,16.3)$ \\
\hline 65 and over & $16.4(15.0,17.8)$ & $20.0(18.5,21.5)$ & $18.2(17.0,19.5)$ \\
\hline \multicolumn{4}{|l|}{$\begin{array}{l}\text { Deprivation (SIMD2006 } \\
\text { quintile) }\end{array}$} \\
\hline 1 (least deprived) & $22.1(19.7-24.7)$ & $21.3(19.1-23.6)$ & $21.7(19.5-24.0)$ \\
\hline 2 & $21.2(18.9-23.7)$ & $20.2(18.1-22.5)$ & $20.7(18.7-22.9)$ \\
\hline 3 & $20.2(17.7-22.9)$ & $19.9(17.7-22.3)$ & $20.0(17.8-22.5)$ \\
\hline 4 & $19.6(17.3-22.1)$ & $19.6(17.7-21.7)$ & $19.6(17.7-21.7)$ \\
\hline 5 (most deprived) & $17.0(15.3-18.8)$ & $19.0(17.3-20.9)$ & $18.0(16.5-19.7)$ \\
\hline \multicolumn{4}{|l|}{ Education } \\
\hline Degree level or above & $24.0(22.0-26.1)$ & $22.7(20.8-24.7)$ & $23.3(21.64-25.12)$ \\
\hline Below degree level & $45.6(43.4-47.7)$ & $41.2(39.0-43.4)$ & $43.3(41.63-44.93)$ \\
\hline No qualifications & $30.4(28.4-32.5)$ & $36.0(34.2-37.9)$ & $33.3(31.75-34.92)$ \\
\hline Missing & $0.1(0.0-0.3)$ & $0.1(0.0-0.3)$ & $0.1(0.0-0.2)$ \\
\hline \multicolumn{4}{|l|}{ Ethnicity } \\
\hline White & $96.8(95.7-97.7)$ & $97.9(97.1-98.4)$ & $97.4(96.6-97.4)$ \\
\hline $\begin{array}{l}\text { Black and Minority Ethnic } \\
\text { group }\end{array}$ & $2.7(1.9-3.8)$ & $1.8(1.3-2.5)$ & $2.2(1.7-3.0)$ \\
\hline Missing & $0.5(0.2-0.9)$ & $0.4(0.2-0.7)$ & $0.4(0.3-0.7)$ \\
\hline \multicolumn{4}{|l|}{ Marital status } \\
\hline Never married & $31.9(29.7-34.1)$ & $25.2(23.2-27.3)$ & $28.4(26.7-30.2)$ \\
\hline Currently married & $56.2(54.0-58.4)$ & $51.1(49.0-53.2)$ & $53.6(51.7-55.5)$ \\
\hline $\begin{array}{l}\text { Divorced, separated or } \\
\text { widowed }\end{array}$ & $11.8(10.8-12.9)$ & $23.6(22.2-25.1)$ & $17.9(17.0-19.0)$ \\
\hline Missing & $0.1(0.0-0.3)$ & $0.1(0.0-0.2)$ & $0.1(0.0-0.3)$ \\
\hline \multicolumn{4}{|l|}{ Economic activity status } \\
\hline Employed & $62.8(60.7-64.9)$ & $49.9(48.0-51.8)$ & $56.1(54.5-57.7)$ \\
\hline Unemployed & $6.5(5.5-7.8)$ & $5.0(4.1-6.0)$ & $5.7(5.0-6.6)$ \\
\hline Retired & $17.8(16.3-19.4)$ & $21.8(20.3-23.3)$ & $19.9(18.6-21.2)$ \\
\hline Economically inactive & $12.7(11.3-14.3)$ & $23.1(21.6-24.7)$ & $18.1(17.0-19.3)$ \\
\hline Missing & $0.1(0.0-0.5)$ & $0.2(0.1-0.7)$ & $0.2(0.1-0.4)$ \\
\hline \multicolumn{4}{|l|}{ Occupational social class } \\
\hline I- professional & $5.3(4.3-6.5)$ & $5.0(4.2-6.1)$ & $5.1(4.4-6.0)$ \\
\hline II - managerial and technical & $20.7(18.9-22.7)$ & $20.3(18.9-21.9)$ & $20.5(19.2-21.9)$ \\
\hline
\end{tabular}


Table 1: Demographic, socioeconomic and behavioural risk factor profile of study sample by sex (Continued)

\begin{tabular}{|c|c|c|c|}
\hline III - skilled & $48.3(46.2-50.5)$ & $48.1(46.1-50.1)$ & $48.2(46.5-49.9)$ \\
\hline IV - partly-skilled & $15.6(14.2-17.1)$ & $15.4(14.0-16.9)$ & $15.5(14.4-16.6)$ \\
\hline V- unskilled & $6.4(5.5-7.5)$ & $8.0(7.1-9.1)$ & $7.3(6.5-8.1)$ \\
\hline Others & $1.1(0.8-1.6)$ & $1.1(0.8-1.5)$ & $1.1(0.9-1.4)$ \\
\hline Missing & $2.6(1.9-3.6)$ & $2.1(1.6-2.8)$ & $2.4(1.9-3.0)$ \\
\hline \multicolumn{4}{|l|}{ Smoking status } \\
\hline Current & $33.8(31.8-35.8)$ & $30.3(28.6-32.1)$ & $32.0(30.6,33.4)$ \\
\hline \multicolumn{4}{|l|}{ Drinking status } \\
\hline $\begin{array}{l}\text { > recommended sensible } \\
\text { level* }\end{array}$ & $28.2(26.4-30.0)$ & $15.2(13.8-16.7)$ & $21.4(20.2,22.6)$ \\
\hline \multicolumn{4}{|l|}{$\begin{array}{l}\text { Fruit and vegetable } \\
\text { consumption }\end{array}$} \\
\hline$<5$ portions/day & $79.6(77.8-81.2)$ & 77.1 (75.4-78.6) & $78.3(76.9,79.6)$ \\
\hline \multicolumn{4}{|l|}{ Overweight/obesity } \\
\hline $\mathrm{BMI} \geq 25 \mathrm{~kg} / \mathrm{m}^{2}$ & $65.8(64.2-67.5)$ & $60.0(58.2-61.8)$ & $62.8(61.4,64.1)$ \\
\hline \multicolumn{4}{|l|}{ Physical activity } \\
\hline$<5$ episodes/week & $59.2(57.1-61.4)$ & $70.5(68.8-72.1)$ & $65.1(63.6,66.6)$ \\
\hline
\end{tabular}

more, the detailed pathways and mechanisms between the socioeconomic determinants and the risk factors investigated cannot be fully determined from this study.

These behaviours were self-reported and are not all externally validated or entirely objective measures. Respondents might tend to give answers that would con-

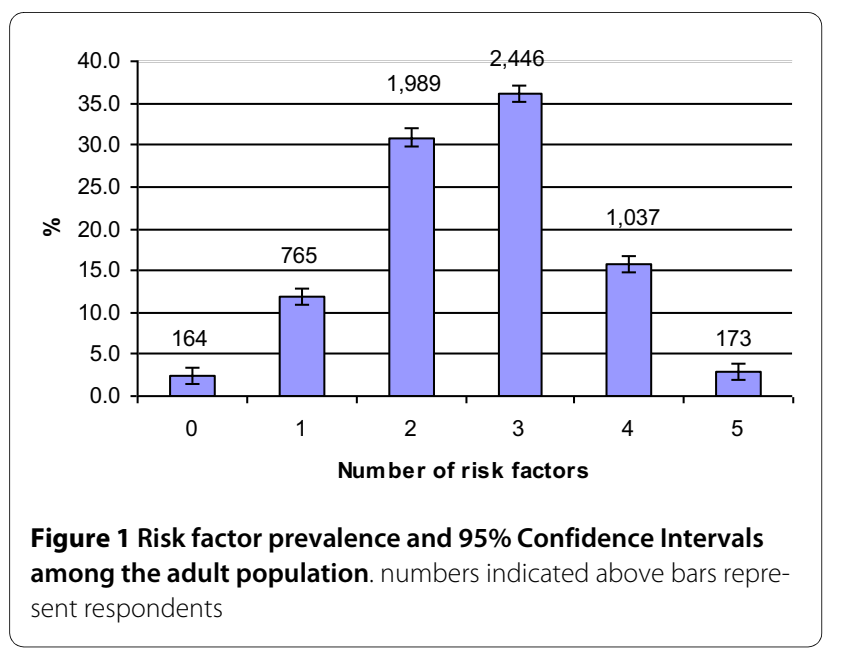

vey more favourable behaviours. This was confirmed for alcohol consumption by an analysis comparing selfreported alcohol intake in the Scottish Health Surveys with alcohol sales estimates which suggested that surveys may understate alcohol consumption by as much as $50 \%$ [10]. Validation of self-reported smoking data using salivary cotinine levels found that that the proportion of men who smoked rose from $32 \%$ (self-reported) to $35 \%$ (validated), and the proportion of women from $28 \%$ to $31 \%$, indicating some under-reporting of smoking [12]. Nevertheless, the Scottish Health Survey is recognised as providing a useful source of data to quantify behaviours and health at the population level with no evidence of substantial socioeconomic response bias [12,19].

For most of the risk factors, presence or absence is relatively straightforward. Diet and nutrition however is a much more complex behaviour than other risk factors. In order to simplify it to a binary dietary measure fruit and vegetable consumption in line with current recommendations was used. This is only one aspect of diet and nutrition, and in terms of healthy weight, does not necessarily mean that total calorie consumption is within certain limits for example. Overall, therefore, the most 
Table 2: Ranked prevalence of all risk factors and combinations of multiple behavioural risk factors

\begin{tabular}{|c|c|c|c|c|c|c|}
\hline \multicolumn{7}{|c|}{ Risk factor } \\
\hline $\begin{array}{c}\text { Number of risk } \\
\text { factors }\end{array}$ & Smoking & $\begin{array}{l}\text { Risky alcohol } \\
\text { drinking }\end{array}$ & $\mathrm{BMI} \geq 25 \mathrm{~kg} / \mathrm{m}^{2}$ & Physically inactive & Diet low in fruit and veg & Prevalence (\%) \\
\hline 5 & $\mathrm{Y}$ & $\mathrm{Y}$ & Y & $\mathrm{Y}$ & $\mathrm{Y}$ & $2.9(2.4,2.5)$ \\
\hline 4 & $\mathrm{Y}$ & $\mathrm{N}$ & Y & $\mathrm{Y}$ & Y & $7.7(7.0,8.5)$ \\
\hline 4 & $\mathrm{~N}$ & $\mathrm{Y}$ & Y & $\mathrm{Y}$ & $\mathrm{Y}$ & $4.0(3.5,4.6)$ \\
\hline 4 & Y & Y & $\mathrm{N}$ & Y & Y & $2.0(1.7,2.4)$ \\
\hline 4 & $\mathrm{Y}$ & $\mathrm{Y}$ & $\mathrm{Y}$ & $\mathrm{N}$ & $\mathrm{Y}$ & $1.6(1.3,2.0)$ \\
\hline 4 & Y & $\mathrm{Y}$ & $\mathrm{Y}$ & $\mathrm{Y}$ & $\mathrm{N}$ & $0.5(0.3,0.5)$ \\
\hline 3 & $\mathrm{~N}$ & $\mathrm{~N}$ & Y & $\mathrm{Y}$ & $\mathrm{Y}$ & $19.5(18.5,20.6)$ \\
\hline 3 & Y & $\mathrm{N}$ & $\mathrm{N}$ & $\mathrm{Y}$ & $\mathrm{Y}$ & $5.9(5.3,6.5)$ \\
\hline 3 & Y & $\mathrm{N}$ & Y & $\mathrm{N}$ & $\mathrm{Y}$ & $3.1(2.7,3.6)$ \\
\hline 3 & $\mathrm{~N}$ & Y & Y & $\mathrm{N}$ & Y & $2.4(2.0,2.8)$ \\
\hline 3 & Y & Y & $\mathrm{N}$ & $\mathrm{N}$ & Y & $1.5(1.2,1.9)$ \\
\hline 3 & $\mathrm{~N}$ & Y & $\mathrm{N}$ & $Y$ & $\mathrm{Y}$ & $1.4(1.1,1.7)$ \\
\hline 3 & $Y$ & $\mathrm{~N}$ & Y & $\mathrm{Y}$ & $\mathrm{N}$ & $1.0(0.8,1.4)$ \\
\hline 3 & $\mathrm{~N}$ & $\mathrm{Y}$ & $\mathrm{Y}$ & $\mathrm{Y}$ & $\mathrm{N}$ & $0.9(0.7,1.3)$ \\
\hline 3 & Y & Y & $Y$ & $\mathrm{~N}$ & $\mathrm{~N}$ & $0.3(0.2,0.5)$ \\
\hline 3 & $Y$ & $Y$ & $\mathrm{~N}$ & $Y$ & $\mathrm{~N}$ & $0.1(0.1,0.3)$ \\
\hline 2 & $\mathrm{~N}$ & $\mathrm{~N}$ & $\mathrm{~N}$ & $\mathrm{Y}$ & $\mathrm{Y}$ & $9.7(8.8,10.7)$ \\
\hline 2 & $\mathrm{~N}$ & $\mathrm{~N}$ & $\mathrm{Y}$ & $\mathrm{N}$ & $\mathrm{Y}$ & $8.0(7.3,8.7)$ \\
\hline
\end{tabular}


Table 2: Ranked prevalence of all risk factors and combinations of multiple behavioural risk factors (Continued)

\begin{tabular}{|c|c|c|c|c|c|c|}
\hline 2 & $\mathrm{~N}$ & $\mathrm{~N}$ & $\mathrm{Y}$ & $Y$ & $\mathrm{~N}$ & $5.8(5.2,6.4)$ \\
\hline 2 & $Y$ & $\mathrm{~N}$ & $N$ & $\mathrm{~N}$ & $Y$ & $2.9(2.4,3.5)$ \\
\hline 2 & $\mathrm{~N}$ & $Y$ & $\mathrm{~N}$ & $\mathrm{~N}$ & $Y$ & $1.3(0.9,1.7)$ \\
\hline 2 & $\mathrm{~N}$ & $Y$ & Y & $\mathrm{N}$ & $\mathrm{N}$ & $1.1(0.8,1.4)$ \\
\hline 2 & $Y$ & $\mathrm{~N}$ & $\mathrm{~N}$ & Y & $\mathrm{N}$ & $0.7(0.5,1.0)$ \\
\hline 2 & $Y$ & $\mathrm{~N}$ & Y & $\mathrm{N}$ & $\mathrm{N}$ & $0.6(0.4,0.9)$ \\
\hline 2 & $\mathrm{~N}$ & $Y$ & $\mathrm{~N}$ & Y & $\mathrm{N}$ & $0.5(0.3,0.7)$ \\
\hline 2 & $\mathrm{Y}$ & $Y$ & $\mathrm{~N}$ & $\mathrm{~N}$ & $\mathrm{~N}$ & $0.4(0.3,0.6)$ \\
\hline 1 & $\mathrm{~N}$ & $\mathrm{~N}$ & $N$ & $\mathrm{~N}$ & $Y$ & $4.6(4 \cdot 0,5.1)$ \\
\hline 1 & $\mathrm{~N}$ & $\mathrm{~N}$ & Y & $\mathrm{N}$ & $\mathrm{N}$ & $3.4(2.9,3.9)$ \\
\hline 1 & $\mathrm{~N}$ & $\mathrm{~N}$ & $\mathrm{~N}$ & Y & $\mathrm{N}$ & $2.5(2.1,3.0)$ \\
\hline 1 & $Y$ & $\mathrm{~N}$ & $N$ & $\mathrm{~N}$ & $\mathrm{~N}$ & $0.7(0.5,1.0)$ \\
\hline 1 & $\mathrm{~N}$ & $Y$ & $N$ & $\mathrm{~N}$ & $\mathrm{~N}$ & $0.6(0.4,1.0)$ \\
\hline
\end{tabular}

$\mathrm{Y}=$ included in combination of risk factors

$\mathrm{N}=$ excluded in combination of risk factors

BMI - Body Mass Index

important aspects of diet are likely to be: total calorie consumption; total fat consumption; salt consumption; sugar consumption; and fruit and vegetable consumption. Therefore, ideally a dietary risk factor should consider each of these. Nevertheless, for the purposes of comparison with other studies and as a measure of diet recognised to be particularly important to health we utilised a variable related to fruit and vegetable consumption. It is increasingly recognised that overweight and obesity are being investigated as separate categories [20], and analysis in this way is likely to have highlighted further the associations between deprivation and obesity.

The socioeconomic measures used in this analysis are not necessarily entirely representative of all aspects of socioeconomic circumstances. Area-based deprivation, individual-level educational attainment, marital status, occupational social class, employment activity status and ethnicity do not capture the full picture of social, eco- nomic, and demographic determinants. For example, individual and household income are known to be related to risk factor behaviours but were not available in this analysis. Residual confounding by socioeconomic status therefore remains a possibility.

The strengths of the analysis include the rigour of the methods used for the Scottish Health Survey. The response rate for the survey was $67 \%$ of all eligible households. The large population sample is reflected in the precision and tight confidence interval of prevalence estimates. However, it is likely that a lower percentage of individuals would have participated which potentially could reduce the representative of the response and increase the risk of socioeconomic bias. The Scottish Health Survey is generally considered to be a socioeconomically representative sample [12,19], however the full data available in this analysis indicate some skewing of response to those less deprived quintiles. Therefore any 
Table 3: Multinomial logistic regression for combinations of multiple risk factors ${ }^{1}$, in adults aged 16 years and over. All factors are mutually adjusted for each other

\begin{tabular}{|c|c|c|c|}
\hline Variable (n) & (2) vs (0 or 1 ) risk factors 1 & (3) vs (0 or 1 ) risk factors 1 & (4 or 5$)$ vs ( 0 or 1 ) risk factors 1 \\
\hline & \multicolumn{3}{|c|}{$\operatorname{RRR}(95 \% \mathrm{CI})$} \\
\hline \multicolumn{4}{|l|}{ Sex } \\
\hline tWomen $(3,663)$ & 1.00 & 1.00 & 1.00 \\
\hline Men $(2,941)$ & $1.12(0.93,1.33) \mathrm{n} / \mathrm{s}$ & $1.28(1.09,1.50) * *$ & $1.81(1.51,2.19) * * *$ \\
\hline \multicolumn{4}{|l|}{ Age } \\
\hline$\dagger 16-24(567)$ & 1.00 & & 1.00 \\
\hline $25-34(860)$ & $1.08(0.75,1.56) \mathrm{n} / \mathrm{s}$ & $1.70(1.10,2.62) *$ & $1.65(1.06,2.56) *$ \\
\hline $35-44(1,357)$ & $1.20(0.80,1.80) \mathrm{n} / \mathrm{s}$ & $1.84(1.25,2.71)^{* *}$ & $1.74(1.15,2.63) * *$ \\
\hline $45-54(1,178)$ & $1.06(0.69,1.62) \mathrm{n} / \mathrm{s}$ & $1.90(1.22,2.95) * *$ & $1.79(1.13,2.82) *$ \\
\hline $55-64(1,203)$ & $1.19(0.78,1.81) \mathrm{n} / \mathrm{s}$ & $1.84(1.15,2.95) *$ & $1.51(0.92,2.48) \mathrm{n} / \mathrm{s}$ \\
\hline $65+(1,409)$ & $1.19(0.66,2.17) \mathrm{n} / \mathrm{s}$ & $2.00(1.08,3.71) *$ & $0.88(0.48,1.64) \mathrm{n} / \mathrm{s}$ \\
\hline \multicolumn{4}{|c|}{ Deprivation (SIMD2006 quintile) } \\
\hline †1 (Least Deprived) $(1,313)$ & 1.00 & 1.00 & 1.00 \\
\hline $2(1,425)$ & $0.96(0.74,1.26) \mathrm{n} / \mathrm{s}$ & $0.92(0.71,1.2) \mathrm{n} / \mathrm{s}$ & $0.98(0.70,1.36) \mathrm{n} / \mathrm{s}$ \\
\hline $3(1,467)$ & $0.93(0.69,1.24) \mathrm{n} / \mathrm{s}$ & $1.01(0.77,1.31) \mathrm{n} / \mathrm{s}$ & $1.09(0.78,1.52) \mathrm{n} / \mathrm{s}$ \\
\hline $4(1,265)$ & $1.04(0.78,1.38) \mathrm{n} / \mathrm{s}$ & $1.25(0.95,1.65) \mathrm{n} / \mathrm{s}$ & $1.35(1.00,1.82) \mathrm{n} / \mathrm{s}$ \\
\hline 5 (Most Deprived) $(1,104)$ & $1.75(1.24,2.48) * *$ & $2.21(1.60,3.06)^{* * *}$ & $3.20(2.28,4.49) * * *$ \\
\hline \multicolumn{4}{|c|}{ Highest Educational Qualification } \\
\hline †Degree or above $(1,518)$ & 1.00 & & 1.00 \\
\hline Below degree level $(2,626)$ & $1.33(1.06,1.67) *$ & $1.68(1.37,2.05)^{* * *}$ & $1.90(1.49,2.41) * * *$ \\
\hline No qualifications $(2,426)$ & $1.86(1.40,2.48) * * *$ & $3.18(2.38,4.25) * * *$ & $3.14(2.31,4.26) * * *$ \\
\hline
\end{tabular}


Table 3: Multinomial logistic regression for combinations of multiple risk factors ${ }^{1}$, in adults aged 16 years and over. All factors are mutually adjusted for each other (Continued)

\begin{tabular}{|c|c|c|c|}
\hline Race/ethnicity & & & \\
\hline tWhite $(6,440)$ & 1.00 & & 1.00 \\
\hline BME (109) & $0.44(0.23,0.83) *$ & $0.32(0.16,0.65)^{* *}$ & $0.16(0.06,0.41)^{* * *}$ \\
\hline \multicolumn{4}{|l|}{ Marital Status } \\
\hline †Never Married $(1,496)$ & 1.00 & 1.00 & 1.00 \\
\hline Currently Married $(3,744)$ & $0.86(0.69,1.09) \mathrm{n} / \mathrm{s}$ & $1.01(0.79,1.30) \mathrm{n} / \mathrm{s}$ & $1.04(0.78,1.39) \mathrm{n} / \mathrm{s}$ \\
\hline $\begin{array}{l}\text { Divorced, separated, widowed } \\
(1,329)\end{array}$ & $1.01(0.72,1.41) \mathrm{n} / \mathrm{s}$ & $1.10(0.77,1.56) \mathrm{n} / \mathrm{s}$ & $1.46(0.99,2.16) \mathrm{n} / \mathrm{s}$ \\
\hline \multicolumn{4}{|l|}{ Economic Activity Status } \\
\hline †Employed $(3,540)$ & 1.00 & 1.00 & 1.00 \\
\hline Unemployed (295) & $0.90(0.57,1.42) \mathrm{n} / \mathrm{s}$ & $0.98(0.65,1.45) \mathrm{n} / \mathrm{s}$ & $0.99(0.61,1.61) \mathrm{n} / \mathrm{s}$ \\
\hline Retired $(1,555)$ & $1.63(1.10,2.42) *$ & $1.66(1.16,2.37)^{* *}$ & $2.07(1.38,3.10) * * *$ \\
\hline Economically inactive $(1,177)$ & $0.98(0.73,1.31) \mathrm{n} / \mathrm{s}$ & $1.13(0.88,1.47) \mathrm{n} / \mathrm{s}$ & $1.60(1.21,2.11) * *$ \\
\hline \multicolumn{4}{|l|}{ Occupational Social Class } \\
\hline †' professional (325) & 1.00 & 1.00 & 1.00 \\
\hline II managerial \& technical $(1,384)$ & $1.16(0.79,1.69) \mathrm{n} / \mathrm{s}$ & $1.05(0.74,1.49) \mathrm{n} / \mathrm{s}$ & $1.11(0.68,1.80) \mathrm{n} / \mathrm{s}$ \\
\hline III skilled $(3,132)$ & $1.70(1.18,2.46) * *$ & $1.42(1.00,2.04) \mathrm{n} / \mathrm{s}$ & $2.05(1.24,3.39) * *$ \\
\hline IV partly skilled $(1,055)$ & $1.65(1.10,2.48) *$ & $1.46(1.01,2.11) *$ & $1.89(1.15,3.12) *$ \\
\hline V unskilled (490) & $1.70(1.05,2.76) *$ & $1.72(1.04,2.83) *$ & $2.19(1.17,4.10) *$ \\
\hline Others (77) & $1.50(0.51,4.43) \mathrm{n} / \mathrm{s}$ & $1.60(0.61,4.22) \mathrm{n} / \mathrm{s}$ & $1.78(0.57,5.5) \mathrm{n} / \mathrm{s}$ \\
\hline
\end{tabular}

participation bias would likely contribute to even greater associations with low socioeconomic status/circumstances. We also found no differences in the SIMD profile of those included with all five risk factors compared with those excluded. The survey used weights to correct for survey design (large households were underrepresented) and non-response biases [12]. Furthermore, the age distribution corresponds to the 2003 General Register Office for Scotland (GROS) mid-year population estimates, where the proportion of the adult population in the agegroups (used in this analysis) were: 16-24 years - 14.2\%; 
25-34 years - 15.7\%; 35-44 years - 19.3\%; 45-54 years $16.6 \%$; $55-64$ years - 14.3\%; and 65+years - $19.9 \%$.

Comparing our findings with analyses of combinations of multiple risk factors from health surveys from across the world (Table 4), the Scottish population seems to have among the lowest rates of absence of any behavioural risk factors and highest rates of multiple risk factors. Higher prevalence of multiple risk factors was observed in Scotland than in USA [5,8], Finland [6], Netherlands [7], Switzerland [9], New Zealand [21], and Canada [22], although similar findings were observed for the English population in the same year [23]. The strong associations of multiple risk factors with low socioeconomic status observed in the Scottish population were found noted in other surveys - particularly low educational attainment [5-8], but also low occupational social class [23]. This study uniquely found strong associations with both area-based and individual level socioeconomic measures and clustering of risk factors.

Table 4: Comparison with health surveys from across the world

\begin{tabular}{|c|c|c|c|c|c|}
\hline Reference & $\begin{array}{l}\text { Setting/ } \\
\text { Country }\end{array}$ & Study Design & $\begin{array}{l}\text { Risk Factors Included in } \\
\text { Study }\end{array}$ & Main Findings & $\begin{array}{l}\text { Comparing risk factor } \\
\text { combinations in } \\
\text { common with our } \\
\text { data }\end{array}$ \\
\hline $\begin{array}{l}\text { Poortinga } \\
\text { (2007) [23] }\end{array}$ & England 2003 & $\begin{array}{l}11,492 \text { subjects in the } \\
\text { Health Survey for } \\
\text { England }\end{array}$ & $\begin{array}{l}\text { smoking } \\
\text { risky alcohol drinking } \\
\text { physical inactivity } \\
\text { diet low in fruit/vegetables }\end{array}$ & $\begin{array}{l}26 \% \text { had } 3+\text { risk factors } \\
6 \% \text { had no risk factors }\end{array}$ & $\begin{array}{l}27 \% \text { had } 3+\text { risk factors } \\
6 \% \text { had no risk factors }\end{array}$ \\
\hline $\begin{array}{l}\text { Tobius et al } \\
(2007)[21]\end{array}$ & $\begin{array}{l}\text { New Zealand } \\
2002 / 03\end{array}$ & $\begin{array}{l}\text { Over } 17,000 \text { subjects in } \\
\text { New Zealand Health } \\
\text { Survey }\end{array}$ & $\begin{array}{l}\text { smoking } \\
\text { risky alcohol drinking } \\
\text { physical inactivity } \\
\text { diet low in fruit/vegetables }\end{array}$ & $\begin{array}{l}13 \% \text { had } 3+\text { risk factors } \\
29 \% \text { had no risk factors. }\end{array}$ & $\begin{array}{l}27 \% \text { had } 3+\text { risk factors } \\
6 \% \text { had no risk factors }\end{array}$ \\
\hline $\begin{array}{l}\text { Chiolero et al } \\
(2006)[9]\end{array}$ & $\begin{array}{l}\text { Switzerland } \\
2002\end{array}$ & $\begin{array}{l}18,000 \text { subjects from } \\
\text { the } 2002 \text { Swiss Health } \\
\text { Survey }\end{array}$ & $\begin{array}{l}\text { smoking } \\
\text { risky alcohol drinking } \\
\text { physical inactivity } \\
\text { diet low in fruit/vegetables }\end{array}$ & $\begin{array}{l}8 \% \text { had } 3+\text { risk factors } \\
30 \% \text { had no risk factors }\end{array}$ & $\begin{array}{l}27 \% \text { had } 3+\text { risk factors } \\
6 \% \text { had no risk factors }\end{array}$ \\
\hline $\begin{array}{l}\text { Fine et al } \\
(2004)[8]\end{array}$ & USA 2001 & $\begin{array}{l}30,000 \text { subjects from } \\
\text { the National Health } \\
\text { Interview Survey }\end{array}$ & $\begin{array}{l}\text { smoking } \\
\text { risky alcohol drinking } \\
\text { physical inactivity } \\
\text { overweight }\end{array}$ & $\begin{array}{l}17 \% \text { had } 3+\text { risk factors } \\
10 \% \text { had no risk factors }\end{array}$ & $\begin{array}{l}41 \% \text { had } 3+\text { risk factors } \\
7 \% \text { had no risk factors }\end{array}$ \\
\hline $\begin{array}{l}\text { Klein-Geltink } \\
\text { et al (2006) [22] }\end{array}$ & Canada 2000 & $\begin{array}{l}\text { Over } 100,000 \text { subjects } \\
\text { in the Community } \\
\text { Health Survey }\end{array}$ & $\begin{array}{l}\text { smoking } \\
\text { risky alcohol drinking } \\
\text { physical inactivity } \\
\text { overweight }\end{array}$ & $\begin{array}{l}8 \% \text { had } 3+\text { risk factors } \\
21 \% \text { had no risk factors }\end{array}$ & $\begin{array}{l}41 \% \text { had } 3+\text { risk factors } \\
7 \% \text { had no risk factors }\end{array}$ \\
\hline $\begin{array}{l}\text { Schuit et al } \\
(2002)[7]\end{array}$ & $\begin{array}{l}\text { Netherlands } \\
\text { 1993-97 }\end{array}$ & $\begin{array}{l}17,000 \text { subjects in the } \\
\text { Dutch population } \\
\text { survey }\end{array}$ & $\begin{array}{l}\text { smoking } \\
\text { risky alcohol drinking } \\
\text { physical inactivity } \\
\text { diet low in fruit/vegetables }\end{array}$ & $\begin{array}{l}20 \% \text { had } 3+\text { risk factors } \\
10 \% \text { had no risk factors }\end{array}$ & $\begin{array}{l}27 \% \text { had } 3+\text { risk factors } \\
6 \% \text { had no risk factors }\end{array}$ \\
\hline $\begin{array}{l}\text { Laaksonen et } \\
\text { al (2001) [6] }\end{array}$ & Finland 1991-98 & $\begin{array}{l}23,000 \text { subjects in the } \\
\text { Health Behaviour } \\
\text { Among Finnish Adult } \\
\text { Population project }\end{array}$ & $\begin{array}{l}\text { smoking } \\
\text { risky alcohol drinking } \\
\text { physical inactivity } \\
\text { diet low in fruit/vegetables }\end{array}$ & $\begin{array}{l}10 \% \text { had } 3+\text { risk factors } \\
33 \% \text { had no risk factors }\end{array}$ & $\begin{array}{l}27 \% \text { had } 3+\text { risk factors } \\
6 \% \text { had no risk factors }\end{array}$ \\
\hline $\begin{array}{l}\text { Berrigan et al } \\
(2003)[5]\end{array}$ & USA 1988-94 & $\begin{array}{l}15,000 \text { subjects from } \\
\text { the Third National } \\
\text { Health and Nutrition } \\
\text { Survey }\end{array}$ & $\begin{array}{l}\text { smoking } \\
\text { risky alcohol drinking } \\
\text { physical inactivity } \\
\text { diet low in fruit/vegetables } \\
\text { diet high in fat. }\end{array}$ & $\begin{array}{l}18 \% \text { had } 3+\text { risk factors } \\
6 \% \text { had no risk factors }\end{array}$ & $\begin{array}{l}27 \% \text { had } 3+\text { risk factors } \\
6 \% \text { had no risk factors }\end{array}$ \\
\hline
\end{tabular}


The health implications for individuals of multiple behavioural risk factors are underexplored. There are few examples where combined behavioural risk factors are implicated in aetiology. Combined smoking and alcohol are reported to synergistically increase the risk of upper aerodigestive tract cancer [24]; and combinations of the "Framingham" risk factors which include smoking, and physical inactivity have been found to account for most of the risk associated with cardiovascular disease [25].

Socioeconomic determinants seem to have an effect on multiple behavioural risk factors at both the individual and area-level. Both low educational attainment and residence in a deprived community were strongly associated with multiple risk factors.

The role of educational attainment in health and in health behaviours is yet to be fully 'unbundled' [26]. Potential mechanisms could include low education level: (i) acting as a direct causal effect - as it is generally fixed in early life it may also reflect childhood experiences [27]; (ii) influencing position in society and the inferred stresses [28,29]; (iii) reflecting income and access to health care and health information [30]; (iv) influencing occupation [31]; (v) determining values for the future [32]; (vi) as a means of developing cognitive skills and so decision-making [32]; (vii) affecting preferences and so locus of control [32]; and (viii) determining social/peer networks [32].

The explanation of the effect of residence in an area of high deprivation on the prevalence of multiple risk factors is worth considering. Deprivation is measured here by SIMD - an area-based socioeconomic measure deprivation. While use of area measures has previously been criticised as producing an 'ecological fallacy' - as individuals are allocated an area socioeconomic status based on their residence - this may in fact help with an explanation. A convincing case that the ecological perspective (and the way it is measured in terms of socioeconomic level) can provide important insights has been proposed $[33,34]$. The argument follows that the socioeconomic environment affects health and wellbeing apart from or over and above that of the individual. Macintyre and Ellaway's (2000) distinction between contextual (place related) and compositional (people related) are the key elements in this multi-level perspective [34].

Area deprivation could impact on behavioural risk factors through a range of potential pathways, including: (i) economic and social deprivation related to the physical environment (e.g. healthy food access, availability of low cost alcohol, poor housing, environmental pollution, transport, recreational facilities); (ii) economic and social deprivation related to the social environment (including 'social trauma' from e.g. fear of crime, social isolation, discrimination; and 'physical trauma' from e.g. alcohol, smoking culture); (iii) targeted marketing of harmful products to deprived area; (iv) inadequate area-services (e.g. education, health, transport, recreation).

A potential explanation for the relationship between socioeconomic determinants and multiple risk factors is "cultural". Frolich et al (2001) describe the 'collective lifestyles' model of community behaviour as potentially a way of capturing the collective or cultural dimension of behaviours [35]. They described this as behaviours being integral to social practices and norms. Continuing the cultural explanation, Hanlon et al. (2005) recently explored the possibility of what they described as a 'Scottish effect' to explain higher mortality rates in Scotland than in England and Wales between 1981 and 2001, when a decreasing influence of socioeconomic deprivation was observed in the data. While the 'Scottish effect' was not fully defined, one interesting possibility raised was the cultural explanation. This was described as arising from social factors and in particular deprivation, which potentially impact on the collective psyche, affecting health through behaviours [36].

Whereas health and social services input to addressing risk factors have generally focussed on individual risk factors, the move towards 'anticipatory care' in Scotland is leading to a more holistic approach exemplified by the national anticipatory care programme 'Keep Well' [37]. This recognises that there may be more than one risk factor present in individuals. Assessment through anticipatory care can lead to a plan of action for an individual taking into account readiness to change, and considering the other risk factors and the socioeconomic context.

On a population-wide basis we need to further improve aspects of the physical and social and economic environment which predispose to alcohol misuse, smoking, lack of physical activity and poor nutrition. Recent policy documents from the Scottish Government show a level of commitment to legislation in relation to smoking and alcohol. There is also a commitment to looking at healthy weight, although policy in relation to the economy and in particular industries in food, energy and transport seems to override this. There is a real need to bring these policies together with social and economic policy to ensure change. The socioeconomic determinants of these behavioural risk factors need to be more explicitly acknowledged and understood.

\section{Conclusions}

It is reasonable to conclude that the vast majority of the population have something to gain in terms of current or future health by identifying and addressing risk factors. Healthy behaviours do not seem to cluster while unhealthy behaviours cluster - this is important insight into how to tackle risk factors both from a population public health and individual patient perspective. Furthermore these risk factors are strongly associated with low 
socioeconomic circumstances. Health services, health improvement, and anticipatory care approaches and policy need to respond by becoming more joined up. These findings also support the continuation in efforts to tackle health inequalities via both a population and individual high-risk approaches to prevention and risk reduction.

\section{Abbreviations}

BME: Black and Minority Ethnic groups; BMI: Body Mass Index; SIMD: Scottish Index of Multiple Deprivation

\section{Competing interests}

The authors declare that they have no competing interests.

\section{Authors' contributions}

All authors developed the study design. DIC, OH, RL planned and coordinated the work. RL undertook the statistical analysis. DIC wrote the first draft of the manuscript and coordinated feedback. All authors contributed to revising manuscript, and all authors read and approved the final manuscript.

\section{Acknowledgements}

The Scottish Health Survey data are publicly available via UK Data Archive http://www.data-archive.ac.uk/findingData/shlsTitles.asp. Secondary analysis of this dataset was undertaken by NHS National Services Scotland Information Services Division.

\section{Author Details}

IInformation Services Division, NHS National Services Scotland, Gyle Square, Edinburgh, UK, ${ }^{2}$ Department of Public Health, NHS Forth Valley Health Board, Stirling, UK, ${ }^{3}$ Department of Public Health Sciences, University of Edinburgh, Edinburgh, UK and ${ }^{2}$ Dental School, Faculty of Medicine, University of Glasgow, Glasgow, UK

Received: 19 October 2009 Accepted: 11 June 2010

Published: 11 June 2010

\section{References}

1. Ezzati M, Vander Hoorn S, Lopez AD, Goodarz D, Rogers A, Mathers CD Murray CJL: Comparative Quantification of Mortality and Burden of Disease Attributable to Selected Risk Factors. In Global Burden of Disease and Risk Factors Edited by: Lopez AD, Mathers CD, Ezzati M, Jamieson DT, Murray CJL. New York: Oxford University Press; 2006:241-268.

2. NHS Health Scotland ISD Scotland / ASH Scotland: An atlas of tobacco smoking in Scotland. 2007 [http://www.scotpho.org.uk/nmsruntime/ saveasdialog.asp? ||D=3907\&sID=3256]. Edinburgh, NHS Health Scotland (accessed May 2010)

3. World Cancer Research Fund/American Institute for Cancer Research: Food, Nutrition, Physical Activity, and the Prevention of Cancer: a Global Perspective. Washington DC: AICR; 2007.

4. Orleans CT: Addressing multiple behavioral health risks in primary care; broadening the focus of health behavior change research and practice. Am J Prev Med 2004, 27:1-3.

5. Berrigan D, Dodd K, Troiano RP, Krebs-Smith SM, Barbash RB: Patterns of health behavior in U.S. adults. Prev Med 2003, 36:615-23.

6. Laaksonen M, Prättälä R, Karisto A: Patterns of unhealthy behaviour in Finland. Eur J Public Health 2001, 11:294-300.

7. Schuit AJ, van Loon AJM, Tijhuis M, Ocke MC: Clustering of lifestyle risk factors in a general adult population. Prev Med 2002, 35:219-24.

8. Fine LJ, Philogene GS, Gramling R, Coups EJ, Sinha SI: Prevalence of multiple chronic disease risk factors. 2001 National Health Interview Survey. Am J Prev Med 2004, 27(s.2):18-24.

9. Chiolero A, Wietlisbach V, Ruffieux C, Paccaud F, Cornuz J: Clustering of risk behaviors with cigarette consumption: A population-based survey. Prev Med 2006, 42:348-353.

10. Catto S, Gibbs D: How much are Scots really drinking? A review of data from Scotland's routine national surveys. Glasgow: NHS Health Scotland; 2008.
11. Gray L, Leyland AH: A multilevel analysis of diet and socio-economic status in Scotland: investigating the Glasgow effect. Eur J Public Health 2008, 18:616-21

12. Bromley C, Sprogston K, Shelton N, (eds.): The Scottish Health Survey 2003. 2005 [http://www.scotland.gov.uk/Publications/2005/11/ 25145024/50278]. Edinburgh: The Stationary Office (accessed May 2010)

13. Working Party of the Royal College of Physicians, UK: Alcohol--can the NHS afford it? Recommendations for a coherent alcohol strategy for hospitals. London: Royal College of Physicians; 2001.

14. Williams $C$ : Healthy eating: clarifying advice on fruit and vegetable consumption. BMJ 1995, 310:1453-5.

15. World Health Organization: Diet, Nutrition and the Prevention of Chronic Diseases. Geneva: WHO; 2003. Report of a Joint FAO/WHO Expert Consultation. WHO Technical Report Series no. 916

16. Cole TJ, Bellizzi MC, Flegal KM, Dietz WH: Establishing a standard definition for child overweight and obesity worldwide: international survey. BMJ 2000, 320:1240-3.

17. Health Education Authority London: Sports Council: The Allied Dunbar National Fitness Survey. London: Sports Council; 1992.

18. Scottish Government: Scottish Index of Multiple Deprivation 2006 2006 [http://www.scotland.gov.uk/Topics/Statistics/SIMD/. Edinburgh: Scottish Government (accessed May 2010)

19. Gray L, Batty GD, Craig P, Stewart C, Whyte B, Finlayson A, Leyland AH: Cohort Profile: The Scottish Health Surveys Cohort: linkage of study participants to routinely collected records for mortality, hospital discharge, cancer and offspring birth characteristics in three nationwide studies. Int J Epidemiol 2010, 39:345-350.

20. World Health Organisation: Global Strategy on Diet, Physical Activity and Health. Geneva: WHO; 2004.

21. Tobius M, Jackson G, Yeh L-G, Huang K: Do healthy and unhealthy behaviours cluster in New Zealand. Australian New Zealand J Pub Health 2007, 31:155-163.

22. Klein-Geltink JE, Choi BC, Fry RN: Multiple exposures to smoking, alcohol, physical inactivity and overweight: Prevalences according to the Canadian Community Health Survey Cycle 1.1. Chronic Dis Canada 2006, 27:25-33

23. Poortinga $W$ : The prevalence and clustering of four major lifestyle risk factors in an English adult population. Preventive Med 2007, 44:124-8.

24. Blot WJ, McLaughlin JK, Winn DM, Austin DF, Greenberg RS, PrestonMartin S, Bernstein L, Schoenberg JB, Stemhagen A, Fraumeni JF: Smoking and drinking in relation to oral and pharyngeal cancer. Cancer Res 1988, 48:3282-7.

25. Yusuf S, Hawkens $S$, Ounpuu S, et al.: Effect of potentially modifiable risk factors associated with myocardial infarction in 52 countries (the INTERHEART study): case-control study. Lancet 2004, 364:937-52.

26. Yen $\mathrm{IH}$, Moss $\mathrm{N}$ : Unbundling education: a critical discussion of what education confers and how it lower risk for disease and death. Ann NY Acad Sci 1999, 896:350-1.

27. Lynch JW, Kaplan GA, Cohen RD, et al.: Childhood and adult socioeconomic status as predictors of mortality in Finland. Lancet 1994, 343:524-7.

28. Marmot M, Wilkinson RG: Social determinants of health. 2nd edition Oxford: Oxford University Press; 2006

29. Droomers M, Schrijvers CTM, Stronks K, van de Mheen D, Mackenbach JP: Educational differences in excessive alcohol consumption: the role of psychological and material stressors. Prevent Med 1999, 29:1-10.

30. Marmot MG: The influence of income on health: the views of an epidemiologist. Health Affairs 2002, 21:31-46.

31. Leclerc A, Pietri F, Boitel L, Chastang J-F, Carval P, Blondet M: Level of education, lifestyle, and morbidity in two groups of white collar workers. J Epidemiol Community Health 1992, 46:403-8.

32. Berkman LF, Macintyre S: The measurement of social class in health studies: old measures and new formulations. In Social inequalities and cancer Volume 138. Edited by: Kogevinas M, Pearce N, Susser M, Boffetta P. Lyon: IARC Sci Publ; 1997:51-63.

33. Pearce N: The ecological fallacy strikes back. J Epidemiol Community Health 2000, 54:326-327.

34. Macintryre S, Ellaway A: Ecological approaches: rediscovering the role of the physical and social environment. In Social epidemiology Edited by: Berkman LF, Kawachi I. Oxford University Press: New York; 2000:332-348. 
35. Frohlich K, Corin E, Potvin L: A theoretical proposal for the relationship between context and disease. Soc Health IIIness 2001, 23:776-97.

36. Hanlon P, Lawder RS, Buchanan D, Redpath A, Walsh D, Wood R, Bain M, Brewster DH, Chalmers C: Why is mortality higher in Scotland than in England and Wales? Decreasing influence of socioeconomic deprivation between 1981 and 2001 supports the existence of a 'Scottish Effect'. J Public Health 2005, 27:199-204.

37. NHS Scotland: Keep Well Programme. [http://

www.keepwellscotland.com/]. (accessed May 2010)

\section{Pre-publication history}

The pre-publication history for this paper can be accessed here: http://www.biomedcentral.com/1471-2458/10/330/prepub

\section{doi: 10.1186/1471-2458-10-330}

Cite this article as: Lawder et al., Is the Scottish population living dangerously? Prevalence of multiple risk factors: the Scottish Health Survey 2003 BMC Public Health 2010, 10:330

Submit your next manuscript to BioMed Central and take full advantage of:

- Convenient online submission

- Thorough peer review

- No space constraints or color figure charges

- Immediate publication on acceptance

- Inclusion in PubMed, CAS, Scopus and Google Scholar

- Research which is freely available for redistribution

Submit your manuscript at www.biomedcentral.com/submit
C) Biomed Central 